\title{
MATEMATIKA KREATIF SEBAGAI UPAYA PENINGKATAN KOMPETENSI LULUSAN PROGRAM STUDI PENDIDIKAN MATEMATIKA
}

\author{
Dafid Slamet Setiana \\ dafid.setiana@ustjogja.ac.id \\ Universitas Sarjanawiyata Tamansiswa
}

\begin{abstract}
The Asean Economic Community (MEA) has both positive and negative impacts. To address this, the quality of Indonesian Human Resources is needed for competition in the race for jobs. Thus an effort should be made to provide students with a variety of knowledge to improve competence so as to improve the development of the times. In order to produce quality human resources, it also requires a quality education system. One effort that can be done is to increase the competence of the struggle of tertiary institutions. Mathematics education graduates will enter the workforce as educators. The demands of the world of work are very high in competence to have good competence. Complete mathematics consisting of interrelated concepts is not easily conveyed. All the explanations above, to complete the mathematics education that can be obtained through development and to improve competence in accordance with the KKNI, it is necessary to improve the quality of learning. Efforts to improve the quality of learning can be done in various ways, one of the way that can be done by learning mathematics through creative mathematics. Creative mathematics can be interpreted as learning mathematics with a variety of methods and using learning media that is in accordance with the learning material and in accordance with the level of student ability. Thus through creative mathematics learning, it is hoped that it will further enhance learning competence, especially for mathematics education programs.
\end{abstract}

Keyword: creative mathematics, learning competence

\section{Abstrak}

Masyarakat Ekonomi Asean (MEA) memberi dampak positif maupun negatif. Untuk menyikapi hal tersebut, kualitas Sumber Daya Manusia (SDM) orang Indonesia sangat perlu ditingkatkan untuk menghadapi persaingan dalam memperebutkan lapangan pekerjaan.Dengan demikian perlu dilakukan suatu usaha untuk membekali mahasiswa dengan berbagai ilmu untuk meningkatkan kompetensinya sehinga dapat menyesuaikan perkembangan jaman. Agar dapat menghasilkan SDM yang berkualitas diperlukan juga suatu sistem pendidikan yang berkualitas. Salah satu upaya yang dapat dilakukan adalah dengan meningkatkan kompetensi lulusan perguruan tinggi. Lulusan pendidikan matematika nantinya akan terjun di dunia kerja sebagai pendidik. Tuntutan dunia kerja yang sangat tinggi memaksa lulusan untuk memiliki kompetensi yang baik.Terlebih matematika sebagai ilmu yang terdiri dari konsep-konsep yang saling berkaitan tentunya tidak mudah untuk disampaikan. Berangkat dari beberapa penjelasan di atas, untuk menyiapkan lulusan pendidikan matematika yang dapat mengikuti perkembangan serta dapat meningkatkan kompetensi lulusan sesuai dengan KKNI maka perlu adanya peningkatan kualitas pembelajaran.Upaya meningkatkan kualitas pembelajaran dapat dilakukan dengan berbagai hal, salah satu hal yang dapat dilakukan yaitu dengan pembelajaran matematika melalui matematika kreatif.Matematika kreatif dapat diartikan sebagai pembelajaran matematika dengan metode yang bervariasi serta menggunakan media pembelajaran yang sesuai dengan materi pembelajaran maupun sesuai dengan tingkat kognitif siswa. Dengan demikian melalui pembelajaran matematika kreatif diharapkan akan lebih meningkatkan kompetensi lulusan, terutama bagi lulusan 
program studi pendidikan matematika.

Kata kunci: matematika kreatif, kompetensi lulusan

\section{ARTICLE HISTORY:}

Received: 11 Desember 2019, Revised: 21 Februari 2020

Accepted: 4 April 2020, Onlinefirst: 7 April 2020

\section{PENDAHULUAN}

Masyarakat Ekonomi Asean (MEA) memberikan kebebasan bagi warga negara ASEAN untuk bepergian masuk dan keluar dari kawasan lain tanpa memerlukan visa (Evinea, dkk., 2014). Bagi Indonesia, hal ini tentunya memberi dampak positif maupun negatif. Dampak positif diantaranya warga Negara Indonesia dapat memperoleh manfaat untuk mendapatkan pekerjaan dan memilih pekerjaan yang diinginkan ke luar wilayah Indonesia. Tetapi sebaliknya Indonesia juga akan didatangi oleh pencari kerja dari luar Indonesia. Hal ini mengakibatkan peluang kerja di Indonesia juga akan semakin berkurang dan persaingan semakin ketat. Untuk menyikapi hal tersebut, kualitas Sumber Daya Manusia (SDM) orang Indonesia sangat perlu ditingkatkan untuk menghadapi persaingan dalam memperebutkan lapangan pekerjaan.

Persaingan dalam memperoleh pekerjaan tentu juga berlaku bagi lulusan perguruan tinggi untuk semua bidang ilmu. Dengan demikian perlu dilakukan suatu usaha untuk membekali mahasiswa dengan berbagai ilmu untuk meningkatkan kompetensinya sehinga dapat menyesuaikan perkembangan jaman.

Pendidikan merupakan hal yang sangat penting dalam kehidupan. Pendidikan diperlukan manusia sepanjang hayat. Selain itu, pendidikan merupakan upaya untuk meningkatkan kualitas Sumber Daya Manusia (SDM) baik fisik, mental, dan spiritual. Oleh karena itu pendidikan harus ditumbuhkembangkan secara sistematis sehingga tercipta suatu sistem pendidikan yang dapat menghasilkan SDM yang berkualitas. Agar dapat menghasilkan SDM yang berkualitas diperlukan juga suatu sistem pendidikan yang berkualitas. Pemerintah selalu berusaha meningkatkan mutu pendidikan nasional melalui perubahan sistem pendidikan nasional dengan berbagai macam komponen yang terdapat di dalamnya. Salah satu bentuk perubahan tersebut adalah perbaikan kurikulum antara lain diberlakukannya kurikulum 2015 yang diselaraskan dengan KKNI.

Kerangka Kualifikasi Nasional Indonesia (KKNI), lulusan setara S1 harus memiliki beberapa kompetensi antara lain : (1) Mampu mengaplikasikan bidang 
keahliannya dan memanfaatkan IPTEKS pada bidangnya dalam penyelesaian masalah serta mampu beradaptasi terhadap situasi yang dihadapi, (2) Menguasai konsep teoritis bidang pengetahuan tertentu secara umum dan konsep teoritis bagian khusus dalam bidang pengetahuan tersebut secara mendalam serta mampu memformulasikan penyelesaian masalah prosedural, (3) Mampu mengambil keputusan yang tepat berdasarkan analisis informasi dan data, dan mampu memberikan petunjuk dalam memilih berbagai alternatif solusi secara mandiri dan kelompok, (4) Bertanggung jawab pada pekerjaan sendiri dan dapat diberi tanggung jawab atas pencapaian hasil kerja organisasi. Dengan berlakunya KKNI diharpakan pembelajaran berpusat pada mahasiswa, mahasiswa menjadi lebih aktif dan mandiri sehingga mampu menguasai konsep lebih mendalam yang pada akhirnya berpengaruh terhadap prestasi belajar mahasiswa.

Mahasiswa yang memilih keahlian kependidikan tentunya memiliki kompetensi yang berbeda dengan yang lain. Lebih khususnya mahasiswa pendidikan matematika. Lulusan pendidikan matematika nantinya akan terjun di dunia kerja sebagai pendidik. Tuntutan dunia kerja yang sangat tinggi memaksa lulusan untuk memiliki kompetensi yang baik. Terlebih matematika sebagai ilmu yang terdiri dari konsep-konsep yang saling berkaitan tentunya tidak mudah untuk disampaikan.

Berangkat dari beberapa penjelasan di atas, untuk menyiapkan lulusan pendidikan matematika yang dapat mengikuti perkembangan serta dapat meningkatkan kompetensi lulusan sesuai dengan KKNI maka perlu adanya peningkatan kualitas pembelajaran. Upaya meningkatkan kualitas pembelajaran dapat dilakukan dengan berbagai hal, salah satu hal yang dapat dilakukan yaitu dengan pembelajaran matematika melalui matematika kreatif. Matematika kreatif dapat diartikan sebagai pembelajaran matematika dengan metode yang bervariasi serta menggunakan media pembelajaran yang sesuai dengan materi pembelajaran maupun sesuai dengan tingkat kognitif siswa. Pembelajaran matematika kreatif dapat dipelajari dan disiapkan semenjak mahasiswa masih belajar di bangku perkuliahan, sehingga pada saat terjun di dunia kerja sebagai pendidik, mereka mampu melaksanakan pembelajaran matematika dengan baik. Pembelajaran tidak hanya sebagai transfer of knowledge tetapi bagaimana mengajak siswa untuk aktif dalam pembelajaran. 
Adapun tujuan penulisan artikel ini adalah untuk mendeskripsikan cara meningkatkan kompetensi lulusan program studi pendidikan matematika melalui matematika kreatif. Adapun manfaatnya yaitu sebagai masukan bagi pendidik dan pemerhati pendidikan dalam menyusun rencana dan melaksanakan pembelajaran matematika sehingga dalam pembelajaran matematika di samping untuk mencapai penguasaan konsep oleh mahasiswa sekaligus juga meningkatkan kompetensi lulusan.

\section{PEMBAHASAN}

\section{Pembelajaran Matematika}

Pembelajaran dalam pandangan konstruktivis adalah penyediaan lingkungan belajar yang konstruktif. Lingkungan belajar yang konstruktif menurut Hudojo (1998) adalah lingkungan belajar yang, (1) menyediakan pengalaman belajar yang mengaitkan pengetahuan baru dengan pengetahuan yang telah dimiliki siswa sehingga belajar merupakan proses pembentukan pengetahuan, (2) Menyediakan berbagai alternatif pengalaman belajar, (3) mengintegrasikan pembelajaran dengan situasi realistik dan relevan dengan melibatkan pengalaman konkret, (4) Mengintegrasikan pembelajaran yang terjadinya interaksi dan kerja sama antar siswa, (5) Memanfaatkan berbagai media agar pembelajaran lebih menarik, dan (6) Melibatkan siswa secara emosional dan sosial sehingga matematika lebih menarik dan siswa mau belajar (Trianto, 2010).

Pembelajaran menurut Degeng dalam Uno (2005) adalah upaya untuk membelajarkan siswa. Oleh karena itu, dalam belajar siswa tidak hanya berinteraksi dengan guru sebagai salah satu sumber belajar tetapi juga berinteraksi dengan seluruh sumber belajar yang mungkin dapat dipakai untuk memcapai tujuan pembelajaran. Oleh karena itu, pembelajaran menaruh perhatian pada 'bagaimana membelajarkan siswa' dan bukan pada 'apa yang dipelajari siswa.

Menurut Dimyati (2006), pembelajaran adalah kegiatan guru secara terprogram dalam desain instruksional, untuk membuat siswa belajar secara aktif, yang menekankan pada penyediaan sumber belajar. Pembelajaran berarti aktivitas guru dalam merancang bahan pengajaran agar proses pembelajaran dapat berlangsung secara efektif, yakni siswa dapat belajar aktif dan bermakna (Susanto, 2013).

Prinsip pembelajaran (the learning principles) dalam matematika sekolah yang dirumuskan National Council of Teachers of Mathematics (NCTM) adalah "students 
must learn mathematics with understanding, actively building new knowledge from experience and prior knowledge”. Artinya siswa harus mempelajari matematika melalui pemahaman serta secara aktif membangun pengetahuan baru. Trianto (2012) menyatakan hal serupa, siswa harus mengkronstruksikan pengetahuan di benak mereka sendiri. Jadi belajar matematika tidak hanya sekedar menghafal. Dalam kegiatan pembelajaran guru berfungsi sebagai fasilitator dan motivator, guru bertanggungjawab untuk menciptakan situasi yang kondusif yang mendorong prakarsa, motivasi, dan tanggung jawab siswa untuk belajar (Dhoruri, 2010).

Pada hakikatnya, program pembelajaran bertujuan tidak hanya memahami dan menguasai apa dan bagaimana suatu terjadi, tetapi juga memberi pemahaman dan penguasaan tentang "mengapa hal itu terjadi" (Wena, 2009). Nasution (1992) menyatakan tujuan belajar yang utama ialah bahwa apa yang dipelajari itu berguna di kemudian hari, yakni membantu kita untuk dapat belajar terus dengan cara yang lebih mudah. Pembelajaran matematika adalah suatu proses belajar mengajar yang dibangun oleh guru untuk mengembangkan kreativitas berpikir siswa yang dapat meningkatkan kemampuan berpikir siswa, serta dapat meningkatkan kemampuan mengkonstruksi pengetahuan baru sebagai upaya meningkatkan penguasaan yang baik terhadap materi matematika (Susanto, 2013).

Menurut Umar H. Malik (2005), pembelajaran adalah suatu usaha mengorganisasikan lingkungan untuk menciptakan kondisi belajar bagi siswa. Sedangkan Zainal (2006) menyatakan bahwa pembelajaran merupakan kombinasi tersusun meliputi unsur manusia, material, fasilitas, perlengkapan, dan rancangan yang saling mempengaruhi untuk mencapai tujuan pembelajaran. Pendapat senada juga dikemukakan oleh Gagne dan Briggs dalam Mukminan (2004), pembelajaran didefinisikan sebagai suatu rangkaian kegiatan yang mempengaruhi pembelajar sehingga prosesnya berlangsung dengan indah. Dimyati dan Mudjijono (1999) berpendapat bahwa pembelajaran adalah kegiatan guru secara terprogram dalam desain instruksional untuk membuat siswa belajar secara aktif, melalui penyediaan sumber belajar.

Dalam proses pembelajaran matematika, baik guru maupun siswa bersama-sama menjadi pelaku terlaksananya tujuan pembelajaran. Tujuan pembelajaran ini akan mencapai hasil yang maksimal apabila pembelajaran berjalan secara efektif. 
Pembelajaran yang efektif adalah pembelajaran yang mampu melibatkan seluruh siswa secara aktif. Kualitas pembelajaran dapat dilihat dari segi proses dan hasil. Jika dilihat dari segi proses, pembelajaran dikatakan berhasil dan berkualitas apabila seluruhnya atau sebagian besar siswa terlibat secara aktif, baik fisik, mental, maupun sosial dalam proses pembelajaraan, disamping menunjukan semangat belajar yang tinggi, dan percaya pada diri sendiri.

Menurut Wragg (1997), pembelajaran yang efektif adalah pembelajaran yang memudahkan siswa untuk mempelajari sesuatu yang bermanfaat, seperti fakta, keterampilan, nilai, konsep, dan bagaimana hidup serasi dengan sesama atau suatu hasil belajar yang diinginkan (Susanto, 2013). Dengan demikian, diketahui bahwa proses pembelajaran matematika bukan sekedar transfer ilmu dari guru ke siswa, melainkan suatu proses kegiatan, yaitu terjadi interaksi antara guru dengan siswa serta antara siswa dengan siswa, dan antara siswa dengan lingkungannya. Selain itu, juga dapat dipahami bahwa pembelajaran matematika bukan hanya sebagai transfer of knowledge, yang mengandung makna bahwa siswa merupakan objek dari belajar, namun hendaknya siswa menjadi subyek dalam belajar.

Pembelajaran matematika merupakan proses pembelajaran dengan menggunakan simbol-simbol matematika yang banyak dipengaruhi oleh sistem penalaran dan intelegensi. Menurt pendapat para ahli, dapat disimpulkan bahwa pembelajaran matematika merupakan proses yang melibatkan guru dan siswa. Dengan demikian pembelajaran matematika seharusnya menjadikan siswa aktif berperan dalam proses pembelajaran sehingga pembelajaran bermakna bagi siswa. Proses belajar siswa akan terjadi ketika pengetahuan yang sedang dipelajari bermakna (Wijaya, 2012).

Berdasarkan uraian di atas, dapat disimpulkan bahwa pembelajaran matematika merupakan suatu aktivitas kegiatan belajar mengajar yang dibangun oleh guru untuk mengembangkan kreativitas berpikir siswa, meningkatkan kemampuan berpikir siswa, serta meningkatkan kemampuan mengkonstruksi pengetahuan baru melalui aktivitas pemecahan masalah, mencari masalah dengan menempatkan realitas dan pengalaman siswa sebagai titik awal pembelajaran. Sementara siswa dalam memperoleh pengetahuannya tidak menerima secara pasif, melainkan pengetahuan dibangun oleh siswa itu sendiri secara aktif. 


\section{Kompetensi Lulusan}

Pendidikan berbasis kompetensi menekankan pada kemampuan yang harus dimiliki oleh lulusan suatu jenjang pendidikan. Kompetensi yang sering disebut dengan standar kompetensi adalah kemampuan yang secara umum harus dikuasai lulusan. Kompetensi lulusan merupakan modal utama untuk bersaing ditingkat global, karena persaingan yang terjadi adalah pada kemampuan sumber daya manusia. Oleh karena itu, penerapan pendidikan berbasis kompetensi diharapkan akan menghasilkan lulusan yang mampu berkompetisi di tingkat global. Implikasi pendidikan berbasis kompetensiadalah pengembangan silabus dan sistem penilaian berbasis kompetensi. Paradigma pendidikan berbasis kompetensi yang mencakup kurikulum, pembelajaran dan penilaian, menekankan pencapaian hasil belajar sesuai dengan standar kompetensi. Kurikulum berisi bahan ajar yang diberikan kepada mahasiswa melalui proses pembelajaran.

Berdasarkan Keputusan Mendiknas Nomor 045/U/2002 tentang kurikulum inti Pendidikan Tinggi pasal 1, Kompetensi adalah seperangkat tindakan cerdas, penuh tanggung jawab yang dimiliki seseorang sebagai syarat untuk dianggap mampu oleh masyarakat dalam melaksanakan tugas-tugas dalam bidang tertentu. Competencies combine appropriate supporting knowledge and professional attitude, and they are performed reliably in natural settings without assistance (Chambers, 2008). Lebih lanjut Mc Gaghie, et.al, (1978) Competence includes a broad range of knowledge, attitudes, and observable patterns of behavior which together account for the ability to deliver a specified professional service.

Penetapan kompetensi lulusan dibuat berdasarkan profil lulusan yang telah dicanangkan sebelumnya. Profil adalah peran yang diharapkan dapat dilakukan oleh lulusan program studi di masyarakat/dunia kerja. Profil ini adalah outcome pendidikan yang akan dituju. Dengan menetapkan profil, perguruan tinggi dapat memberikan jaminan pada calon mahasiswanya akan bisa berperan menjadi apa saja setelah ia menjalani semua proses pembelajaran di program studinya.

Setelah menetapkan profil lulusan program studi sebagai outcome pendidikan, maka selanjutnya adalah menentukan kompetensi apa saja yang harus dimiliki oleh lulusan program studi sebagai output pembelajarannya. Kompetensi lulusan bisa didapat lewat kajian terhadap tiga unsur yaitu: 1) nilai-nilai yang dicanangkan oleh perguruan tinggi, 2) visi keilmuan dari program studinya, dan 3) kebutuhan masyarakat pemangku 
kepentingan. Kompetensi terbagi dalam tiga kategori yaitu :

a. Kompetensi utama merupakan penciri lulusan sebuah program studi;

b. Kompetensi pendukung adalah kompetensi yang ditambahkan oleh program studi sendiri untuk memperkuat kompetensi utamanya dan memberi ciri keunggulan program studi tersebut;

c. Kompetensi lain adalah kompetensi lulusan yang ditetapkan oleh perguruan tinggi/program studi sendiri sebagai ciri lulusannya dan untuk memberi bekal lulusan agar mempunyai keleluasaan dalam memilih bidang kehidupan serta dapat meningkatkan kualitas hidupnya.

Setelah semua kompetensi lulusan terumuskan, langkah selanjutnya adalah mengkaji apakah kompetensi tersebut telah mengandung kelima elemen kompetensi seperti yang diwajibkan dalam Kepmendiknas No.045/U/2002. Kelima elemen kompetensi tersebut adalah :

a. Landasan Kepribadian;

b. Penguasaan ilmu dan keterampilan;

c. Kemampuan Berkarya;

d. Sikap dan perilaku dalam berkarya menurut tingkat keahlian ilmu berdasarkan ilmu dan keterampilan yang dikuasai;

e. Pemahaman kaidah berkehidupan bermasyarakat sesuai dengan pilihan keahlian dalam berkarya.

Setiap kompetensi lulusan dianalisis apakah mengandung satu atau lebih elemenelemen kompetensi tersebut. Untuk menganalisis adanya muatan elemen kompetensi di setiap kompetensi, salah satu cara yang bisa dilakukan adalah dengan mengecek kemungkinan strategi pembelajaran yang akan diterapkan untuk mencapai kompetensi tersebut.

Jika kompetensi tersebut mengandung elemen (1) landasan kepribadian yang lebih bersifat softskills, nantinya bisa diselipkan dalam bentuk hidden curriculum. Jika kompetensi tersebut mengandung elemen (2) penguasaan ilmu dan keterampilan, maka bisa diajarkan dalam bentuk mata kuliah. Jika kompetensi mengandung elemen (3) kemampuan berkarya, maka kompetensi tersebut bisa ditempuh dengan praktek kerja tertentu, dan bila kompetensi tersebut mengandung elemen (4) sikap dan perilaku dalam berkarya, maka didalam praktek kerja tersebut harus bermuatan sikap dan perilaku. 
Terakhir, bila kompetensi tersebut mengandung elemen (5) pemahaman kaidah berkehidupan bermasyarakat, maka kompetensi tersebut bisa diperoleh dengan strategi praktek kerja di masyarakat.

\section{Pembelajaran Matematika Kreatif}

Suyatno (2009) menyatakan bahwa kreatif merupakan perubahan yang terjadi dari belum ada menjadi ada. Jadi pendidik matematika yang kreatif adalah pendidik yang mampu untuk menciptakan atau melahirkan suatu karya yang baru dan belum ada sebelumnya dalam pembelajaran matematika di dalam kelas. Berkaitan dengan hal tersebut, menurut Ginanto (2011) seorang pendidik yang professional adalah mereka yang mampu menyulap kekurangan menjadi peluang untuk menjadi nilai lebih. Mereka mampu membuat kreasi-kreasi baru dalam mengajar.

Selain kreatif, pendidik juga dituntut untuk inovatif. Menurut Suyatno (2009) inovatif dimaknai sebagai beberapa gagasan dan teknik yang baru. Adapun kata inovasi, berarti pembaharuan. Berdasarkan pengertian-pengertian tersebut, inovasi merupakan sebuah temuan baru baik dalam bentuk ide, barang atau jasa yang berbeda dari sebelumnya dalam lingkungan tertentu, dalam arti kreasi, dimensi dan penampilannya. Kemudian temuan baru itu diproses, dikenalkan secara sistematis dengan maksud agar dimiliki oleh individu lain supaya terjadi perubahan. Jadi pendidik matematika yang kreatif dan inovatif adalah pendidik yang mampu mengeluarkan gagasan dan teknik yang baru dari teknik yang lama sehingga pembelajaran matematika tersebut menjadi menyenangkan dan disenangi oleh peserta didik.

Dalam bidang pendidikan, pihak yang memegang kunci dalam pembangkitan dan pengembangan daya kreativitas peserta didik ialah pendidik. Tantangan pembelajaran matematika sangat membutuhkan pendidik yang kreatif dan inovatif agar peserta didik berminat dan tertarik untuk mempelajari matematika. Menurut Gutama dalam Narwanti (2011), pandai saja tidak cukup, tetapi pendidik harus cerdas dalam mengembangkan keterampilan dan mencari bahan ajar yang betul-betul sesuai dengan peserta didik.

Peranan kreatif dan inovatif pendidik matematika tidak sekedar hanya membantu proses belajar mengajar tetapi juga membantu peserta didik untuk bisa lebih memahami materi dan konsep materi pembelajaran. Beberapa manfaat pendidik matematika kreatif dan inovatif, yaitu : 
1. Pendidik yang kreatif dan inovatif berguna untuk meningkatkan minat peserta didik terhadap mata pelajaran matematika.

2. Kreativitas pendidik matematika berguna dalam transfer ilmu lebih utuh.

3. Kreativitas pendidik berguna dalam merangsang peserta didik untuk lebih berpikir secara ilmiah dalam mengamati gejala masyarakat atau gejala alam yang menjadi objek kajian dalam belajar matematika.

4. Produk kreativitas pendidik matematika akan merangsang kreativitas peserta didik.

Beberapa aktifitas kreatif di kelas dapat meningkatkan kualitas pembelajaran dan hasil belajar matematika. Dalam pengajaran, pendidik diharapkan sering mengajukan pertanyaan yang dapat membangun kemampuan berpikir kritis peserta didik. Pertanyaan kritis tersebut yaitu: Adakah cara lain? (What's another way?), Bagaimana jika...? (What if ...?), Manakah yang salah? (What's wrong?), dan Apakah yang akan dilakukan? (What would you do?) (Krulik \& Rudnick, 1999). Berikut beberapa aktifitas pembelajaran matematika yang dapat meningkatkan hasil belajar dan meningkatkan kualitas lulusan:

1. Menggunakan permainan

2. Gunakan kreativitas alami peserta didik

3. Menggunakan kemampuan pemecahan masalah

\section{SIMPULAN DAN SARAN}

Simpulan dari artikel ini yaitu meningkatkan kompetensi lulusan sangat diperlukan untuk membekali lulusan memasuki dunia kerja, kompetensi lulusan dapat dicapai melalui pembelajaran matematika, untuk meningkatkan kompetensi lulusan dapat dilakukan melalui pembelajaran matematika kreatif. Saran dalam pembelajaran matematika, pendidik sebaiknya juga memperhatikan kompetensi-kompetensi lain yang harus dicapai selain penguasaan konsep oleh mahasiswa. Untuk meningkatkan kompetensi lulusan melalui pembelajaran matematika kreatif, pendidik sebaiknya telah merancang pembelajaran yang akan dilaksanakan sedemikian rupa sehingga ada cukup waktu bagi mahasiswa untuk merefleksikan kemampuannya. Di samping itu pendidik harus meningkatkan kreativitasnya dalam mengelola pembelajaran di kelas, baik dari metode, media, soal, dan sebagainya. 


\section{DAFTAR PUSTAKA}

Chambers, Paul. 2008. Teaching Mathematics: Developing as A Reflective Secondary Teacher.California: Sage Company, Inc.

Dhoruri, Atmini. 2010. Pembelajaran Matematika dengan Pendekatan Matematika Realistik (PMR).Yogyakarta: Karya Ilmiah Jurusan Pendidikan Matematika FMIPA UNY.

Dimyati \& Mudjiono. 2002. Belajar dan Pembelajaran. Jakarta: Rineka Cipta.

Evienia, Benedicta, dkk. 2014. Pandangan Pelaku Pendidikan di Universitas Terhadap Pemberlakuan Masyarakat Ekonomi Asean 2015. Jurnal Bina Ekonomi. Vol 18, No 2.

Ginanto. 2011. Jadi Pendidik Kreatif dan Inspiratif. Jakarta: PT Niaga Swadaya.

Hamalik. 2005. Kurikulum dan Pembelajaran. Jakarta: Bumi Aksara.

Hudojo, Herman. 1998. Mengajar Belajar Matematika. Jakarta: Departemen Pendidikan dan Kebudayaan.

Keputusan Mendiknas Nomor 045/U/2002 tentang kurikulum inti Pendidikan.

Krulik, S. \& Rudnick. 1999. Innovative taks to improve critical and creative thinking skills. Develoving Mathematical Raesoning in Grades K-12, pp.138-145.

Mukminan. 2004. Desain pembelajaran. Yogyakarta: Program Pascasarjana Universitas Negeri Yogyakarta.

Narwanti, Sri. 2011. Pendidikan karakter. Yogyakarta: Familia

Nasution dkk. 1992. Didaktik Asas-asas Mengajar. Jakarta: Bumi Aksara.

Susanto, Ahmad. 2013. Teori Belajar dan Pembelajaran di Sekolah Dasar. Jakarta: Kencana Prenada Media Group.

Suyatno. 2009. Menjelajah Pembelajaran Inovatif. Sidoarjo: Masmedia Buana Pustaka.

Trianto. 2010. Mendesain model Pembelajaran Inovatif-Progesif: Konsep, Landasan dan Implementasinya pada Kurikulum Tingkat Satuan Pendidikan (KTSP). Jakarta: Kencana.

Uno, Hamzah B. 2007. Perencanaan Pembelajaran. Jakarta: Bumi Aksara.

Wena, M. 2009. Strategi Pembelajaran Inovatif Kontemporer: Suatu Tinjauan Konseptual Operasional. Jakarta: PT. Bumi Aksara. 
Wijaya, Ariyadi. 2012. Pendidikan Matematika Realistik: Suatu Alternatif Pendekatan Pembelajaran Matematika. Yogyakarta: Graha Ilmu.

Wragg, E.C. 1997. Keterampilan Mengajar Di Sekolah Dasar. Jakarta : Gramedia.

Zainal, A. 2006. Penelitian Tindakan Kelas. Bandung: Yrama Widya 